\title{
In Search of Bernabé: Politicized Motherhood
}

\author{
Fatima Mujcinovic \\ Westminster College
}

Connecting its storyline to the historical context of the civil war in EI Salvador, this US Latina text dramatizes dehumanizing effects of political violence on individual and collective being. With an emphasis on the dialectical connection between the personal and the social, the novel focuses on individual strategies of survival and resistance in conditions of authoritarianism in order to suggest new forms of political opposition and liberation. Its narrative reveals subversive and empowering aspects of the intimate, as the discourse of motherhood and religiosity reclaims its place in the public sphere and takes a direct stance against violence and oppression.

From the signifier of passivity and peace, mother became a signifier of resistance.

Jean Franco 1

Dramatizing dehumanizing effects of political brutality on individual and collective being, In Search of Bernabé (1993) by Graciela Limón connects its storyline to the historical context of the civil war in El Salvador (1980-1992). The narrative depicts struggles of a Salvadoran mother who loses two sons in personal and collective tribulations. While she searches for her son Bernabé, crossing multiple borders on her way to the U.S., 


\section{Ethnic Studies Review Volume 24}

the mother witnesses the collective suffering of her nation and a continuous legal and human discrimination against refugees. Seeing that her story "is not too different from that of many others" (60), Luz Delcano realizes that she is not alone in her pain and suffering. As the novel progresses, the woman's personal condition and plight extend into a collective state of being, reflecting horrors of the Salvadoran turmoil and pleading for help and solidarity.

Ellen McCracken defines this U.S. Latina novel as a "modified testimonial narrative" that bears witness to specific historical events and engages readers in new interpretive practices. ${ }^{2}$ As in testimonio literature, the personal story of the novel's main protagonist functions as an account of communal experience of sociopolitical oppression and marginalization as well as a testimony to abuse of human rights. While it brings to attention the suffering and struggles of the "foreign other," this type of narration provides an articulation of subaltern voices and a reconstruction of history from below. Employing what Linda Hutcheon calls "historiographic metafiction,"3 Limón's text fuses history and fiction to present "counter-narratives to the official, master-text" 4 and thus reveal ideological constructions of dominant social narratives. In addition the protagonist's personal story integrates a call for social justice and liberation, inviting the reader to empathize with the oppressed and oppose their disenfranchisement. 5 In this way the individual is politicized in order to provide social criticism and initiate social transformation, while the power of its "authentic" experience is employed as a means of granting legitimacy to the project of social revolution and liberation.

\section{The Intimate as a Political Investment}

Emphasizing the connection between the individual and the communal, Limón's text also focuses on individual strategies of survival and resistance in conditions of oppression in order to suggest new forms of political opposition and liberation. As Jean Franco and Amy Kaminsky have shown in their studies of Latin American feminist praxis, 6 roles practiced in the traditionally private sphere can be redefined in the public sphere to counter authoritarian practices of the military state. In this novel, privatized concepts, such as motherhood and reli- 
gious faith, are demonstrated as modes of social agency and oppositional populist movement. When mobilized in the public space, their domestic and private designation, imposed by the division between the private and the social, is re-signified and transfigured into an active social commitment. The novel reveals subversive and empowering aspects of the intimate as the discourse of motherhood and religiosity reclaims its place in the public sphere and takes a direct stance against violence, oppression, and subjugation.

In addition the universality of these concepts reaches the common space of experience, affinity, and understanding and thus points at a possibility of new coalitions. Employing an internationalist perspective, Limón's text aims at cross-national solidarity and identification, and the discourse of motherhood and religion serves as a powerful method of translation between different epistemologies of experience. As it mediates otherness, abstraction, and division, this familiar discourse provides a common point of understanding and coming together, making the testimonial dimension more powerful and effective.

Approaching the romanticized and traditionally conformist concepts in a differential mode, the narrative portrays motherly love and religious commitment leading to oppositional consciousness that initiates resistance to the dominant center of power-the repressive state authority. The author underscores that these concepts themselves convert into modes of power when they become mobilized as oppositional forms of social action and mechanisms of survival under conditions of state violence and oppression.

\section{Confronting Political Patriarchy}

By building a parallel between the disintegration of the Delcano family and the violent destruction of their country, the author calls attention to the inevitable connection between the private and the public realm. In a testimonial and a post-colonial manner Limón uses voices of the subaltern to re-narrativize the dominant socio-political narrative as well as to foreground the urgency of global solidarity and liberation. She develops the theme of 'a mother searching for her lost son' in order to integrate the victim's perspective and evince the 


\section{Ethnic Studies Review Volume 24}

destructive effects of political violence and totalitarian authority. As she emphasizes the connection between familial and national structures, Limón points at the continuum between the abusive patriarchal domination over women and the totalitarian state control over citizen-subjects.

The novel opens up with a Biblical excerpt on incestual rape, setting the tone for the prologue and its theme of patriarchal abuse. The main protagonist, Luz Delcano, is raped by her wealthy grandfather and after his death thrown out of the house by the indifferent family. After this account, the first part of the book is introduced by an excerpt from Time Magazine reporting the 1980 massacre at Archbishop Romero's funeral in San Salvador. Having established a link between the fictional and the factual, the narration in "Part One" takes over the sparse and formal journalistic style of the excerpt and imaginatively recreates the moments of the massacre, providing thus a more immediate and concrete representation. The character of Luz Delcano is again in focus, and this time she is thrown in the midst of political terror and violence. As she is following her son Bernabé in the funeral procession, uniformed soldiers suddenly appear and start shooting at the panic-stricken crowd of people: "Mothers crouched wherever they could in an attempt to protect their babies. Men and women pressed against the cathedral walls hoping to find cover behind a corner or a sharp angle" (23).

The sequence of these episodes points at the connection between the forceful exercise of patriarchal power in the domestic sphere and the authority of a repressive state: the totalitarianism of state power is constituted as an extension of patriarchal domination and its mechanisms of hierarchy, oppression, and violence. This continuum also builds an allegorical meaning for the sociopolitical context: the Salvadoran civil war is translated into an intense physical abuse, or rape, of the civilians, who are in the end outcast by the military social system, having been stripped of humanity and identity. In her own discussion of the novel, Graciela Limón affirms that the rape scene in the book's prologue functions as a metaphor for the Salvadoran civil war. ${ }^{7}$ Corresponding to the logic of the violent act of rape, the political violence, too, may be interpreted as "the final act which obliterates the victims" from the social 
system and transforms them into "silent, invisible, non-existent entities." 8 I make this statement referring to Maria HerreraSobek's argument on the politics of rape in order to reaffirm that state authority and regulation are a continuation of the patriarchal exercise of power. I emphasize that in conditions of authoritarianism and militarism both genders become victimized since a totalitarian social system maintains its power through the subjugation and exclusion of women and disenfranchised men, who occupy subordinate positions in a hierarchical social structure. Any act against such social organization results in silencing and obliteration not only in the social but also in the private space, where the authoritarian system asserts its command over the individual.

Throughout the novel, the author foregrounds the invasiveness of the authoritarian state in an attempt to bring to attention the victimization of innocent civilians. At the same time, as she depicts the horrific conditions of individual and social being under the military regime, Limón shows the emergence of populist resistance, the citizens' refusal to be completely silenced. The novel portrays the Salvadorans being forced into a state of internal exile, since the state has denied them safety in both the domestic and the public space. However the citizens creatively and fearlessly confront the confinement by forming a new public space that allows resistance and oppositional movement. The procession that forms for the funeral of Oscar Romero, described at the beginning of the book, can be interpreted as a direct challenge to the dominant center of state power: disobeying the rule of restricted movement and gathering, the oppressed Salvadorans defiantly assert in public their own presence and the presence of Archbishop Romero. The scene establishes this act as a powerful social protest against the military oppression and a call for liberation and social justice articulated in the discourse of liberation theology. By retaking the public space, the Salvadoran civilians not only acknowledge the reality of oppressive conditions but they also refuse to be imprisoned by its annihilating weight and mechanisms of control. The subversiveness of this agency is manifested in the counter-action of the government that utilizes its military apparatus to sabotage the funeral. Although a peaceful and silent gathering, the outdoor burial 


\section{Ethnic Studies Review Volume 24}

ceremony becomes "transformed into a tableau of horror: exploding hand bombs, wild gunfire, terrified crowds stampeding in panic" (19), reports the Time Magazine excerpt in Limón's book.

As the novel illustrates, the sanctioned public space instigated by the totalitarian state does not allow oppositional social movements, and any presence of resistance and subversion is punished and erased by force. However, by reincorporating and reaccentuating the issue of liberation (theology) into the public, the oppositional social movement of the oppressed Salvadorans enters the sanctioned public space and transforms it into a place of resistance and survival. By doing this, the oppressed gain politicized identities that contest the authoritarian system of power and its forms of subjugation. They challenge their muted, objectified positions and re-signify them into sites of social resistance and expression. In her critical study, Talking Back (1992), Debra Castillo explains the resemanticization of silence in the context of patriarchal authority as a form of speech, i.e. an expression of female rebellion and independence. I trace the same process of resemanticization in the silent protests against military regimes in Latin America: the exposure of silence in the public sphere signifies a non-violent stance against state regulations and authority and, at the same time, testifies to the dehumanization and annihilation of the civilian population. Therefore, the objectified others turn into agents of social change and their own emancipation by using the very semantics of oppression and authoritarianism. Embodying the censored speech and silencing, they create a new space of collective expression and visibility that contests the repressive space instituted by the military state.

Limón's book shows that the will for survival and freedom arises as a powerful force of action even in the conditions of complete helplessness and despair. While in the beginning Luz Delcano enters the public space unwillingly and by force (she is thrown out of the Delcanos' house), later on she defiantly remains in it, determined to find her son Bernabé. Not complying with the rule of restricted movement and refusing to stay confined in her house, she embarks on a risky and dangerous search, first on the streets of San Salvador and then across the borders of Guatemala, Mexico, and the U.S. The narrative 
traces her multiple border-crossing as an oppositional movement, this time against the regulative protocols of nationstates. At the border between Guatemala and Mexico Luz stands up to immigration officers who harass a young Salvadoran man. While his nationality, gender, and age mark him as an offender for the immigration officials- "What have we here? A deserter! That's what you are, aren't you?" (58)-the Salvadoran refugee comes to embody the lost son for Luz. Seeing a gun pointed at the man's head, she launches herself at the agent. Witnessing the threat of physical violence, Luz relives the moment of separation from Bernabé, and as she realizes that "Arturo could have been Bernabé" (58) she panics at the possibility of a repeated loss. The "return of the repressed" 9 transitions her into a defensive mode and gives her strength to overpower the immigration officer. Her biological role of motherhood takes on an oppositional and resistant signification, transforming into a social undertaking.

Dramatizing an encounter between a mother who searches for a disappeared son and the immigration authorities who exercise the power of nation-states, the novel emphasizes the entry of women into the public space as a resistant movement against global patriarchy. The subversive power of the "feminine" emerges in resistance against the patriarchal abuse and authority exercised beyond the boundaries of a single nation. In this instance, the maternal asserts itself against international protocols of the cross-border movement and in defiance of regulation and authority. The mother in the story directly challenges the order of the regulated global space, which is institutionalized in an attempt to protect power structures of nationstates. She realizes that her personal tragedy derives from such order and is manipulated for political interests of the dominant power structures.

Latin American feminist praxis has shown that while women's entrance into the public space poses a serious threat to women's lives it also grants them a subversive and non-violent political power that counters state authoritarianism and military dictatorship. With the advance of oppressive governments, the women's movements in Latin America entered the public space and forced the issues of political violence out in the public. 10 They organized around private and communal 


\section{Ethnic Studies Review Volume 24}

issues, protesting non-violently against the military surveillance and terror, and by extension against the patriarchal dominance and abuse. During the military regime in the 1970s and 1980s, Argentine mothers organized silent demonstrations, demanding information about their abducted sons in spite of state regulations against large public gatherings. ${ }^{11}$ They seized the public space in order to politicize the personal issues and expose the connection between the private and the public. As Jean Franco argues, by focusing the issue of the disappeared into the public, the Argentine mothers redefined the public domain and their own roles as mothers and women in the social sphere ("Beyond Ethnocentrism" 503). They represented the image of "private life" publicly, Franco argues, as a contrast to the present reality that destroyed the very family life that the military state had professed to protect (Critical Passions 50). In this Latin American political practice, women emerged as social agents, resisting passivity, erasure, and marginalization. As they refused to forget and be silent, they challenged the system of oppressive state power and its aims of social paralysis, alienation, and erasure necessary for the maintenance of authoritarian state supremacy.

In Limón's novel, In Search of Bernabé, the maternal unmasks authority as both gendered and sociopolitical, demonstrating the necessity of a simultaneous liberation of the individual and the national. In addition this "politicized motherhood" 12 also points out that oppression in conditions of authoritarianism is not limited to only one gender-Luz protects Arturo against the patriarchal abuse and authoritarianism, understanding his own objectified and victimized position. Arturo's escape from the Salvadoran military regime also subverts the authoritarian definition of males as natural agents and guardians of patriarchal power. His defection signifies his refusal to hold up the authority and at the same time reveals the impossibility of his oppositional existence within the system.

Configuring the individual as a site of sociopolitical meaning, Limón's novel problematizes the traditional distinction between the personal and the political. At the same time it demonstrates that the division between the personal and the public collapses in the context where the private is expected to 
be a site of safety and resistance. Although the dichotomy between two spheres is induced by patriarchal forces from outside and within the private realm in order to maintain male dominance, the division also allows home to be a space of resistance to state regulations and violence. When the public space becomes repressive and destructive, the private space may offer some relief and protection by providing nurturing and affirmation to the self endangered by annihilation. As Jean Franco posits, in the conditions of state repression, home becomes a refuge and a site of resistance, retaining the traditional meaning of familial unity and power (Critical Passions 11). However, the boundary between the two spaces is easily violated, as illustrated by Limón's narrative. State violence invades the safety and privacy of home, asserting the link between two spheres and the destructive effects that the repressive social realm has on an individual. Jean Franco sees it as an assault on the formerly "immune" and "sacred" territories-such as the family, church, and university-which become appropriated and controlled by the state as a dominant institution of power (9). In Search of Bernabé illustrates that even the most intimate and sacred concepts of motherhood and religious faith are not spared before political violence. The paradox of this situation is that the invasiveness of the nation-state attacks the very institutions designed as conduits for state power. While the state upholds familial and religious structures as the foundations of its patriarchal order and proponents of authoritarianism, it also brutally destroys these private spheres when they challenge the dominant authority and its patriarchal rules.

The moment of rupture and destruction of the private realm, however, sets into motion the maternal and the religious experience as modes of individual and collective resistance. The culturally encoded concept of motherly commitment to the family-Marianismo as a cult to La Virgen Maria-is transformed from its underlying notion of female passivity, submissiveness, and selfless sacrifice into a powerful mode of resistance to the patriarchal/state authority. Rather than a strictly domestic role, the motherhood is presented as a social liberation process, committed to social justice and solidarity with the poor and oppressed. In Limón's novel Luz's devotedness to her son, like 


\section{Ethnic Studies Review Volume 24}

the devotedness of all mothers of the disappeared children, becomes a potent political force and investment, or, as Franco describes it a "signifier of resistance" (15). By refusing to give up her sons, taken by the patrio-military order, Luz defies the system that imposed on her the very expectation of sacrificial devotion to the family in its effort to prescribe female marginalization, silencing, and confinement to the domestic realm. She uses the agency of maternal caring, nurturing, and protection in the exclusive sphere of the socio-political to challenge the mechanisms of obliteration and regulation. Her desperate effort to locate her sons drives her to confront violence in a fearless and persistent way while giving her strength to survive its dehumanizing effects. In addition Luz practices the principles of motherhood in the communal space, transforming her biological role into communal solidarity and commitment. Experiencing all disappeared Salvadorans as her own children, she shares her pain with other mothers in the refugee shelter in Los Angeles and helps them in their efforts to locate their disappeared sons. She embraces Arturo as her own child, and at the site of his murder she performs the absent communal vigil by singing "a mournful cradle song for a dead son" (85). To the U.S. police she identifies herself as his mother and mourns the repeated loss: "One after another, each of her sons had been taken from her..." (89). The juxtaposition of the maternal nurturing-"a cradle song"-and the violent destruction in this scene intensifies the criticism of violent state repression and emphasizes its link to the patriarchal order of the domestic space.

Positioning the maternal in a communal context, Graciela Limón portrays motherhood as a subversive, oppositional force against the patriarchal regulation of the domestic and public spaces. In this novel, the role of motherhood transcends the domestic space and its essentialist attributes by entering the exclusive public space as a social engagement. The idea that motherly "devotedness to children" can be translated into a genuine "commitment to others" dismantles the patriarchal structure based on exclusion, subjugation, and alienation. It emphasizes communal connectedness where one is always positioned in relation to others through common experience and solidarity. As it underscores the concept of humanity in inter-relations among individuals and groups, this politicized 
type of motherhood fights against authoritarian projects of divisiveness, dehumanization, and obliteration while re-accentuating the importance of a simultaneous liberation of the individual and the communal. Reaching to the community and pointing at the urgency of social transformation, motherhood in this novel becomes a philosophy of compassion, alliance, and liberation.

The emphasis on the communal is also conveyed through the concept of politicized religion. Highlighting the importance of liberation theology in the resistance movement in Central America, Graciela Limón foregrounds new forms of socio-political agency and solidarity based on political activism of the church. The story exposes the dominant social view of the church as a tool of authoritarian social regulation: the religious ethic is relegated to the realm of the private/individual and not to be connected to political activism, since its advocacy of communal support and peace undermines the power structure of the patrio-military social order. The novel's narration captures typical comments of the government officials on the activism of Salvadoran priests. "Priests had best stay out of politics and confine themselves to Mass and to forgiving" (23) Religious teachings are allowed to enter the public space as long as they serve to maintain the existing social structure-by focusing on endurance, patience, obedience, and individual sinfulness, they sustain the status quo and exclude any possibility of social transformation. The politicized progressive religion, as the story illustrates, becomes threatening to authoritarian power structures because it exposes and condemns systemic subjugation and exploitation of the "subordinate" groups. With its discourse of equality and non-violence, it directly challenges the dominant social structure based on patriarchal discrimination and militarism. The liberation theology, specifically, counters the dominant power structure with its assistance to the poor and its promotion of liberation and empowerment of the oppressed. In its effort to contemporize the Biblical teachings on equality and freedom, 13 it brings to light the present conditions of hegemony, oppression, and injustice while pointing at the urgency of national liberation that would grant freedom and agency to the disenfranchised.

The presence of the discourse of liberation theology is 


\section{Ethnic Studies Review Volume 24}

immediately marked at the beginning of the book-the first massacre scene is set at the funeral of Archbishop Oscar Romero, a follower of liberation theology murdered for his oppositional teachings and activism.14 "It was a pity', those faces said to Bernabé, 'that the Archbishop had not heeded his finer instincts, his better judgments"' (23). The Archbishop's role in raising awareness about poverty and his effort to change power relations are presented as a direct challenge to the expectations of his complicity with the system of control, discipline, and hierarchy. The narrative conveys that the presence of his differential movement in the public sphere is seen as a serious threat to the military state, a threat that must be eliminated via his own physical annihilation. His dismissal of patriarchal conduct is regarded by the military order as a lack of masculine qualities-"finer instincts, better judgment"-and this emasculation is used to rationalize the act of exclusion and obliteration. The juxtaposition of religion and militarism in this scene, and throughout the book, intensifies the representation of the military social system as dehumanizing and destructive. Also, while it dramatizes the conditions of living under a military dictatorship, this opposition foregrounds the urgency of communal resistance and empowerment.

The story of seminarian Bernabé carries through the idea of communal liberation as Bernabé is shown engaging in guerrilla fighting to protect the lives of his people. In order to reflect the invasiveness of the oppressive socio-political sphere and the intensification of violence instituted by the authoritarian state, the narrative captures the seminarian's inner struggle to negotiate his personal belief in non-violence with his need to actively confront the enclosing destruction. Bernabé himself becomes a victim as the authoritarian state attacks his non-violent positioning, first through his feminization-"Better pick up your skirt and find a church to hide with other women," (25) an armed soldier warns him-and then by his physical erasure described at the end of the novel. Other liberation activists, both domestic and foreign, working in El Salvador meet a similar end-the narration includes reports of their murder or arrest by the Salvadoran government. The violent counter-action against the liberation theology and peace activism described throughout the novel discloses the full intensity and scope of 
authoritarian state repression. At the same time it also reveals the political significance of progressive religious teaching which is employed to form solidarity and alliances in a joined struggle against oppression.

\section{Demystifying Civil War}

Addressing the U.S. public, for whom the violent conflict in El Salvador was mostly a removed, simulacrumized experience, Limón's book uses personal and universal concepts of motherhood, love, religiosity, and human suffering to humanize distant and unfathomable civil war. Its narrative concretizes the abstracted, depersonalized level of history and politics by effecting affinity through humanity and identification. When guerrilla fighter Nestor tells his life story to Bernabé, the pacifist seminarian feels pain although he himself did not experience Nestor's tragedy. By extension the removed or the pacifist reader, too, feels sympathy for the man who watched the paramilitary rape his sisters and kill his father. In a similar fashion Luz's pain and anguish at the moment of finding the mutilated body of her son reaches all mothers and moves all readers, while the horror of civilian massacres transcends the textual boundaries as an unnerving and alarming experience. This actuality of human suffering breaks through the abstraction of war, asserting that everybody is related on the premise of common humanity. This is why Graciela Limón employs the motif of fratricide, borrowed from the Bible, 15 and insists on international geopolitical connections. As she unmasks the complicity of the U.S. government in the Salvadoran conflict, she also exposes the necessity of a cross-national connection in the process of mourning and healing. The narrative attempts to communicate that the suffering and tragedy of Salvadoran civilians need to be redeemed with an understanding and emotional identification from the U.S. American side. This act of bringing together hopes to generate not only a greater sympathy but also a progressive social action-solidarity and alliance with the oppressed nations and a movement to end both local and global oppression.

The personalized narrative of the civil war in El Salvador expands the boundaries of understanding even further by reaching to the side of the oppressor. Besides the voices of the 


\section{Ethnic Studies Review Volume 24}

oppressed Salvadorans-represented by Luz, Bernabé, and Arturo-the narration legitimizes voices of the perpetrators, too, in order to create an account that includes both sides and thus provides a more complete rendering of sociohistorical events. In this way the novel reconfigures the traditional testimonio approach-where the voice of a victimized informant provides an account of oppression-in order to demystify and deconstruct the logic of violent national conflicts. In a psychoanalytical manner Colonel Delcano's drive to control and abuse others is traced back to his childhood, to the traumatic moment of the enforced separation from his mother and the resulting feelings of abandonment and betrayal. His obsessive desire to know and control is linked to his "child's terror" and "chronic insomnia" (46), and as he is building dossiers on his mother and brother he is also persecuting his countrymen. This connection of one's formative life experiences to the social formation provides an alternative to the official interpretations of wars as "habits of less civilized nations," interpretations predominantly used to cover up one's complicity with violence or one's lack of humanitarian concern. The psychoanalytical explanation asserts again the interlocking of the micro and macro spheres, where an individual is always enmeshed in the oppressive system of the social order governed by patriarchal forces. With Colonel Delcano's trauma connected to his mother's annihilation by patriarchy, his exercise of military state power is presented as a direct outcome of the patriarchal oppression. This relation confirms patriarchal power as the driving force of authoritarianism and emphasizes the vicious cycle of abuse, where individual victimhood and communal oppression foster each other.

Approaching the connection between the personal and the public from multiple and diverse perspectives, In Search of Bernabe exposes both the destructiveness and the political potential of the dialectical conditioning between the social and the subjective. Its personal testimonial narration directly engages with sociopolitical reality to unmask the process of communal victimization and, at the same time, reveal strategies of liberation. Using the concepts of motherly and religious love, the novel shows that in conditions of authoritarianism the intimate, private sphere may engender a powerful sociopolitical 
movement of opposition and resistance.

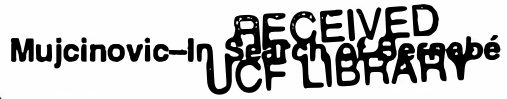

\section{Endnotes}

MAR 152002

1 Jean Franco, Critical Passions 15.

\section{Serials}

2 See McCracken's analysis of Limón's novel in New Latina Narrative, 61.

3 In her critical study The Politics of Postmodernism (London: Routledge, 1989), Linda Hutcheon defines "historiographic metafiction" as a paradoxical postmodem form that includes both history and fiction in its narrative representation having its "historical and sociopolitical grounding sit uneasily alongside its self-reflexivity" (15). The fusion of history and fiction is developed to recreate the past and reinterpret history in a more vivid, immediate, and powerful way. This is a postmodernist effort that answers to the impossibility of objective recording and the arbitrariness of historical meaning. It privileges the value of experience and representation over historical facts recognizing that historical accounts are always ideologically constructed.

4 In her reading of In Search of Bernabe, Ellen Mc Cracken states that Graciela Limón reconfigures a number of biblical motifs and thus presents "a counter-narrative to the master text of organized religion" (New Latina Narrative 61). I expand this to include a counter-narrativization of not only dominant religious discourses but also of dominant sociopolitical and historiographic texts.

5 In her analysis of the testimonio genre, Latin American Women Writers: Class, Race, and Gender, Myriam Yvonne Jehenson states that "the reader is asked to empathize with the marginality of the uneducated native informant" and "to join in the struggle to overcome an oppressive class of which he/she is a member" (140-41). I see this call in more communal terms and as more inclusive of other forms of oppression: in addition to class, I recognize racial, ethnic, linguistic, and gender oppression.

6 See Jean Franco's "Beyond Ethnocentrism" and Critical Passions and Amy Kaminsky's Reading the Body Politic. 


\section{Ethnic Studies Review Volume 24}

7 From Limón's interview given to Ellen McCracken for the biographical entry in Dictionary of Literary Biography: Chicano Writers.

8 Herrera-Sobek, "The Politics of Rape" 249.

9 Freud defines "the return of the repressed" as an involuntary irruption into consciousness of an unacceptable impulse that has been repressed into unconsciousness in the process of psychological defense.

10 See, for example, studies on Latin American women's movements done by Sonia Alvarez, Marguerite Guzman Bouvard, Jean Franco, and Mary Beth Tierney-Tello.

11 The Argentine mothers, known as Madres de la Plaza de Mayo, began their organized gatherings in the aftermath of the political coup in 1976 (which ushered the period of the "Dirty War" in Argentina). They first met in 1977 as a small group of women and soon their numbers grew to include hundreds of women who dared to demand information about their disappeared children. As Marguerite Guzman Bouvard states, they were the only group that dared to confront a repressive military government and gather in public before the presidential palace in the Plaza de Mayo to demonstrate against state violence. In 1977, they openly constituted themselves also as an organization that promoted democratic values, and by the time a constitutional government replaced the military junta in December, 1983, the mothers "transformed the Plaza de Mayo so that it not only reflected power and dissent but also celebrated their unique battle for human rights and their radicalized, collective version of maternity" (2). For a detailed analysis, see Bouvard's Revolutionizing Motherhood: The Mothers of the Plaza de Mayo.

12 Analyzing women's movements in Brazil, Sonia Alvarez describes the phenomenon of mothers' demonstrations as a "politicization of motherhood." For a detailed analysis, see Alvarez's Engendering Democracy in Brazil: Women's Movements in Transition Politics.

13 One of the most significant practices of liberation theology was the reading and re-interpreting of the Bible, which was conducted by 
parish priests who challenged the dominant interpretation of Biblical teachings. The Scripture discussions were adopted by "base communities" (comunidades de base), informal gatherings that practiced religious service and political forums. Specific passages were related to parishioners' daily lives and interpreted in an emancipatory populist mode rather than in compliance with fatalism and submission to social inequality and hierarchy. For a detailed analysis of liberation theology, see James Schall's Liberation Theology in Latin America (San Francisco: Ignatius Press, 1982) and Phillip Berryman's Liberation Theology: Essential Facts about the Revolutionary Movement in Latin America and Beyond (Philadelphia: Temple University Press, 1987).

14 Oscar Amulfo Romero (1917-1980) was ordained to priesthood in 1942 and appointed archbishop of San Salvador in 1977. Although, in the beginning, he was quite conservative in doctrinal matters and very traditional regarding authority, he emerged as a populist leader who aligned himself with the poor and openly denounced state autocracy and violence. In his final pastoral letter, for example, he condemns the doctrine of national security which places "the individual at the total disposal of the state, denies him political rights and creates inequality in the fruits of development" (Keogh 78). It is believed that the murder of Rutilio Grande, Romero's very close friend and one of the most respected pastors in El Salvador, forced the Archbishop to change his views on hierarchy and authority and become more open to progressive and liberationist ideas. Romero was shot to death on March 24, 1980, at the alter in the chapel of the Divine Providence Hospital, a cancer hospital in San Sebastian. For a detailed analysis of Romero's life and work, see Dermot Keogh's study Romero: El Salvador's Martyr.

15 Archbishop Oscar Romero often used this motif in his explanations of the Salvadoran civil war. For example, when he appealed to the govemment soldiers to disobey the orders and stop the repression, he spoke: "Brothers, each one of you is one of us. We are the same people. The campesinos you kill are your own brothers and sisters" (Erdozaín 78). 


\section{Works Cited}

Alvarez, Sonia. Engendering Democracy in Brazil: Women's Movements in Transition Politics. Princeton: Princeton University Press, 1990.

Bouvard, Marguerite Guzman. Revolutionizing Motherhood: The Mothers of the Disappeared. Wilmington, Delaware: SR Books, 1994.

Castillo, Debra. Talking Back: Towards a Latin American Feminist Literary Criticism. Ithaca: Cornell University Press, 1992.

Erdozaín, Plácido. Archbishop Romero: Martyr of Salvador. New York: Orbis Books, 1981.

Franco, Jean. Critical Passions: Selected Essays. Ed. Mary Louse Pratt and Kathleen Newman. Durham; London: Duke University Press, 1999.

-. "Beyond Ethnocentrism: Gender, Power, and the Third-World Intelligentsia." In Marxism and the Interpretation of Culture. Ed. Cary Nelson and Lawrence Grossberg. Urbana: University of Illinois Press, 1988. 503-15.

Freud, Sigmund. A General Selection from the Works of Freud. Ed. John Rickman. New York: Liveright Publishing Co., 1957.

Herrera-Sobek, María. "The Politics of Rape: Sexual Transgression in Chicana Fiction." In Chicana Creativity and Criticism: Charting New Frontiers in American Literature. Ed. María Herrera-Sobek and Helena María Viramontes. Albuquerque: University of New Mexico Press, 1996. 245-56.

Jehenson, Myriam Yvonne. Latin American Women Writers: Class, Race and Gender. Albany: State University of New York Press, 1995.

Kaminsky, Amy. Reading the Body Politic: Feminist Criticism and Latin American Women Writers. Minneapolis; London: University of Minnesota Press, 1993. 
Mujcinovic-In Search of Bernabé

Keogh, Dermot. Romero: El Salvador's Martyr. Dublin: Dominican Publications, 1981.

Limón, Graciela. In Search of Bernabé. Houston: Arte Público Press, 1994.

McCracken, Ellen. New Latina Narrative: The Feminine Space of Postmodern Ethnicity. Tucson: University of Arizona Press, 1999.

—. "Graciela Limón." Biographical entry, In Dictionary of Literary Biography: Chicano Writers. Ed. Francisco Lomelí and Carl R. Shirley, vol. 209. Detroit: The Gale Group, 1999. 127-132.

Tierney-Tello, Mary Beth. Allegories of Transgression and Transformation: Experimental Fiction by Women Writing Under Dictatorship. Albany: State University of New York Press, 1996. 